\title{
Clinical usefulness of T-SPOT.TB in the diagnosis tuberculosis in emergency patients
}

\author{
HU Xiao-min, LIU Jian, LEl Long, YIN Wen* \\ From 2012 PLA Emergency Medicine Annual Congress \\ Beijing, China. 9-12 November 2012
}

\section{Objective}

To evaluate the diagnostic value of an interferon-gamma release assay T-SPOT.TB in tuberculosis of emergency patients.

\section{Methods}

The emergency patients with suspected tuberculosis received T-SPOT.TB assay in the peripheral blood mononuclear cells(PBMCs).

\section{Results}

T-SPOT.TB assay, PPD, anti-TB antibody test, $M$ tuberculosis polymerase chain reaction, acid-fast bacilli stain and cultures for $\mathrm{M}$ tuberculosis were positive in $96.8 \%$ (31/32), 43.7\%(14/32), 21.8\%(7/32), 15.6\%(5/32), 13.0\% $(3 / 23)$ and $4.3 \%(1 / 23)$, respectively, of patients with active tuberculosis. The sensitivity and specificity of the T-SPOT.TB were $96.8 \%$ and $98.3 \%$.

\section{Conclusions}

T-SPOT.TB assay is a rapid and high-sensitive tests for diagnosing tuberculosis in emergency patients.

Submit your next manuscript to BioMed Central and take full advantage of:

- Convenient online submission

- Thorough peer review

- No space constraints or color figure charges

- Immediate publication on acceptance

- Inclusion in PubMed, CAS, Scopus and Google Scholar

- Research which is freely available for redistribution 